\title{
Dampak Pembiayaan BUS dan UUS Terhadap Produk Domestik Bruto Indonesia Berdasarkan Lapangan Usaha
}

\author{
The impact of BUS and UUS financing on Indonesia's gross domestic product based on \\ industrial
}

\author{
Aida Azmi Nabila \\ Program Studi D4 Keuangan Syariah, Politeknik Negeri Bandung \\ E-mail: aida.azmi.ksy16@polban.ac.id
}

\section{Endang Hatma Juniwati}

Jurusan Akuntansi, Politeknik Negeri Bandung

E-mail: endang.hatma@polban.ac.id

\section{Fifi Afiyanti Tripuspitorini}

Jurusan Akuntansi, Politeknik Negeri Bandung

E-mail: fifi.afiyanti@polban.ac.id

\begin{abstract}
Islamic banking has a role to encourage economic development and enhance economic growth. One way to do this is by allocating Islamic banking financing funds to all economic sectors or industrials in Indonesia. There is a mismatch between the growth statistics of financing distribution to Gross Domestic Product based on industrials consisting of seven industrial. This study aims to determine whether or not there is a relationship, constribution, and the effect of financing channeled on Indonesia's Gross Domestic Product. The sample in this study was determined using purposive sampling. This research method is a descriptive method with a quantitative approach. The results of the model test of the effect of BUS and UUS financing on Indonesia's Gross Dometic Product based on the industrial in 2012-2019 show that not all financing has a relationship, constribution, and the effect to Indonesia's Gross Domestic Product based on the industrial.
\end{abstract}

Keywords: financing, industrial, gross domestic product

\section{Pendahuluan}

\subsection{Latar Belakang}

Perbankan Syariah berdiri di Indonesia pada tahun 1992 dan dipelopori oleh berdirinya Bank Muamalat. Perkembangan perbankan syariah di Indonesia telah menjadi tolak ukur keberhasilan keberadaan ekonomi syariah dimana Indonesia sebagai negara mayoritas beragama Islam sangat cocok dan tepat dalam mengembangkan bank dengan prinsip syariah (Anisa \& Tripuspitorini, 2019). Sebagai salah satu lembaga industri keuangan, perbankan syariah mempunyai peran untuk meningkatkan pertumbuhan ekonomi dan mendorong pembangunan ekonomi. Apabila fungsi sistem keuangan berjalan baik, maka kondisi tersebut diharapkan akan membantu meningkatkan produktivitas dan output melalui peningkatan physcial capital ataupun human capital melalui akselerasi variabel produktivitas (Setiawan, 2017). Salah satu cara yang dilakukan adalah dengan cara cara pengalokasian dana pembiayaan perbankan syariah terhadap seluruh sektor ekonomi atau lapangan usaha di Indonesia. Penyaluran dana pembiayaan berdasarkan lapangan usaha ini bertujuan pula untuk meningkatkan Produk Domestik Bruto. Saat ini Indonesia sedang bergerak 
aktif untuk memajukan perekonomian negara (Apriyanthi et al., 2020). Berikut adalah tabel data pembiayaan yang disalurkan oleh Bank Umum Syariah dan Unit Usaha Syariah berdasarkan lapangan usaha dan tabel data Produk Domestik Bruto Indonesia berdasarkan lapangan usaha.

Gambar 1. Tabel Pembiayaan BUS dan UUS Berdasarkan Lapangan Usaha

\begin{tabular}{|c|c|c|c|c|c|c|c|c|}
\hline $\begin{array}{l}\text { LAPANGAN } \\
\text { USAHA }\end{array}$ & $\begin{array}{c}2012 \\
\text { (Miliar } \\
\text { Rupiah) } \\
\end{array}$ & $\begin{array}{c}2013 \\
\text { (Miliar } \\
\text { Rupiah) }\end{array}$ & $\begin{array}{c}2014 \\
\text { (Miliar } \\
\text { Rupiah) }\end{array}$ & $\begin{array}{c}2015 \\
\text { (Miliar } \\
\text { Rupiah) }\end{array}$ & $\begin{array}{c}2016 \\
\text { (Miliar } \\
\text { Rupiah) }\end{array}$ & $\begin{array}{c}2017 \\
\text { (Miliar } \\
\text { Rupiah) } \\
\end{array}$ & $\begin{array}{l}2018 \\
\text { (Miliar } \\
\text { Rupiah) }\end{array}$ & $\begin{array}{c}2019 \\
\text { (Miliar } \\
\text { Rupiah) }\end{array}$ \\
\hline $\begin{array}{l}\text { Pertanian, } \\
\text { Kehutanan, } \\
\text { dan Sarana } \\
\text { Pertanian } \\
\end{array}$ & 27.972 & 38.327 & 56.178 & 109.818 & 144.599 & 172.677 & 198.734 & 224.205 \\
\hline Pertambangan & 22.747 & 33.621 & 47.286 & 60.361 & 75.766 & 83.370 & 72.225 & 66.324 \\
\hline Perindustrian & 48.547 & 67.951 & 120.786 & 185.454 & 220.110 & 243.473 & 269.494 & 309.719 \\
\hline $\begin{array}{l}\text { Listrik, Gas, } \\
\text { dan Air }\end{array}$ & 35.334 & 47.982 & 55.233 & 71.610 & 87.030 & 98.999 & 163.415 & 180.159 \\
\hline Konstruksi & 74.659 & 92.164 & 117.868 & 139.408 & 138.810 & 220.946 & 267.367 & 337.734 \\
\hline $\begin{array}{l}\text { Perdagangan, } \\
\text { Restoran, dan } \\
\text { Hotel }\end{array}$ & 135.481 & 164.077 & 240.539 & 297.746 & 336.186 & 366.752 & 392.867 & 411.860 \\
\hline $\begin{array}{l}\text { Pengangkutan, } \\
\text { Pergudangan, } \\
\text { dan } \\
\text { Komunikasi }\end{array}$ & 42.255 & 64.274 & 133.485 & 152.805 & 129.605 & 123.529 & 116.938 & 110.618 \\
\hline $\begin{array}{l}\text { Jasa Dunia } \\
\text { Usaha }\end{array}$ & 363.211 & 504.976 & 727.133 & 317.105 & 346.550 & 367.580 & 369.352 & 374.732 \\
\hline $\begin{array}{l}\text { Jasa Sosial } \\
\text { Masyarakat }\end{array}$ & 72.753 & 114.792 & 131.085 & 127.989 & 130.194 & 151.999 & 181.786 & 215.007 \\
\hline Lain-lain & 627.376 & 909.132 & 664.123 & 38.727 & 18.953 & 11.646 & 11.310 & 15.114 \\
\hline
\end{tabular}

Sumber: (Otoritas Jasa Kenangan)(data diolah)

Gambar 2. Tabel Produk Domestik Bruto Indonesia Berdasarkan Lapangan Usaha

\begin{tabular}{|c|c|c|c|c|c|c|c|c|}
\hline $\begin{array}{l}\text { LAPANGAN } \\
\text { USAHA }\end{array}$ & $\begin{array}{c}2012 \\
\text { (Miliar } \\
\text { Rupiah) }\end{array}$ & $\begin{array}{c}2013 \\
\text { (Miliar } \\
\text { Rupiah) }\end{array}$ & $\begin{array}{c}2014 \\
\text { (Miliar } \\
\text { Rupiah) }\end{array}$ & $\begin{array}{c}2015 \\
\text { (Miliar } \\
\text { Rupiah) }\end{array}$ & $\begin{array}{c}2016 \\
\text { (Miliar } \\
\text { Rupiah) }\end{array}$ & $\begin{array}{c}2017 \\
\text { (Miliar } \\
\text { Rupiah) }\end{array}$ & $\begin{array}{l}2018 \\
\text { (Miliar } \\
\text { Rupiah) }\end{array}$ & $\begin{array}{c}2019 \\
\text { (Milar } \\
\text { Rupiah) }\end{array}$ \\
\hline $\begin{array}{l}\text { Pertanian, } \\
\text { Kehutanan, } \\
\text { dan Sarana } \\
\text { Pertanian }\end{array}$ & 1.267 .669 & 1.326 .890 & 1.386 .868 & 1.440 .367 & 1.493 .779 & 1.555 .955 & 1.621 .980 & 1.688 .312 \\
\hline Pertambangan & 771.561 & 791.054 & 794.490 & 767.327 & 774.593 & 779.678 & 796.505 & 806.205 \\
\hline Perindustrian & 1.697 .787 & 1.771 .961 & 1.854 .257 & 1.934 .533 & 2.016 .876 & 2.103 .466 & 2.193 .266 & 2.276 .681 \\
\hline $\begin{array}{l}\text { Listrik, Gas, } \\
\text { dan Air }\end{array}$ & 90.722 & 95.345 & 100.929 & 102.263 & 107.643 & 109.538 & 115.528 & 120.438 \\
\hline Konstruksi & 728.226 & 772.719 & 826.615 & 879.163 & 925.040 & 987.924 & 1.048 .083 & 1.108 .424 \\
\hline $\begin{array}{l}\text { Perdagangan, } \\
\text { Restoran, dan } \\
\text { Hotel }\end{array}$ & 1.067 .912 & 1.119 .272 & 1.177 .297 & 1.207 .164 & 1.255 .760 & 1.311 .762 & 1.376 .937 & 1.440 .521 \\
\hline $\begin{array}{l}\text { Pengangkutan, } \\
\text { Pergudangan, } \\
\text { dan } \\
\text { Komunikasi }\end{array}$ & 600.943 & 653.656 & 708.709 & 770.625 & 834.051 & 910.098 & 974.060 & 1.052 .687 \\
\hline $\begin{array}{l}\text { Jasa Dumia } \\
\text { Usaha }\end{array}$ & 626.446 & 675.243 & 714.060 & 762.643 & 817.101 & 861.452 & 903.377 & 967.170 \\
\hline $\begin{array}{l}\text { Jasa Sosial } \\
\text { Masyarakat }\end{array}$ & 593.143 & 624.455 & 651.371 & 690.541 & 716.344 & 740.834 & 787.905 & 834.507 \\
\hline Lain-lain & 115.675 & 123.083 & 134.070 & 144.904 & 156.507 & 170.177 & 185.468 & 204.997 \\
\hline
\end{tabular}

Sumber: (Badan Pusat Statistik Indonesia)(data diolah)

Dari total 10 lapangan usaha yang ada di Indonesia keselarasan antara peningkatan pembiayaan dan peningkatan Produk Domestik Bruto terdapat pada 3 lapangan usaha yaitu: Pertanian, Kehutanan dan Sarana Pertanian; Perindustrian; serta Perdagangan, Restoran, dan Hotel. Selain itu, pada 7 lapangan usaha lainnya terdapat ketidakselarasan antara peningkatan pembiayaan dan peningkatan Produk Domestik Bruto yaitu: Pertambangan; Konstruksi; Listrik, Gas, dan Air; Pengangkutan, Pergudangan, dan Komunikasi; Jasa Dunia Usaha; Jasa Sosial Masyarakat, dan Jasa Lainnya. Berdasarkan hal tersebut maka penulis akan melakukan analisis pada 7 lapangan usaha tersebut sementara 3 sisanya yakni Pertanian, Kehutanan dan Sarana Pertanian; Perindustrian; serta 
Perdagangan, Restoran, dan Hotel tidak akan dianalisis karena tidak terdapat ketidakselarasan yang perlu dianalisis.

Berdasarkan data yang diperoleh serta perbedaan hasil akhir dari penelitian mengenai pertumbuhan pembiayaan yang disalurkan oleh Bank Umum Syariah dan Unit Usaha Syariah terhadap Produk Domestik Bruto, penulis tertarik untuk meneliti adakah hubungan, kontribusi, dan seberapa besarkah pengaruh pembiayaan yang disalurkan BUS dan UUS terhadap Produk Domestik Bruto Indonesia berdasarkan lapangan usaha. Berdasarkan hal tersebut, penulis melakukan penelitian ini dengan judul "Dampak Pembiayaan BUS dan UUS Terhadap Produk Domestik Bruto Indonesia Berdasarkan Lapangan Usaha."

\subsection{Rumusan Masalah}

1. Adakah hubungan, kontribusi serta berapa besar pengaruh pembiayaan yang disalurkan oleh BUS dan UUS berdasarkan lapangan usaha pertambangan terhadap Produk Domestik Bruto Indonesia berdasarkan lapangan usaha pertambangan?

2. Adakah hubungan, kontribusi serta berapa besar pengaruh pembiayaan yang disalurkan oleh BUS dan UUS berdasarkan lapangan usaha kontruksi terhadap Produk Domestik Bruto Indonesia berdasarkan lapangan usaha kontruksi?

3. Adakah hubungan, kontribusi serta berapa besar pengaruh pembiayaan yang disalurkan oleh BUS dan UUS berdasarkan lapangan usaha listrik, gas, dan air terhadap Produk Domestik Bruto Indonesia berdasarkan lapangan usaha listrik, gas, dan air?

4. Adakah hubungan, kontribusi serta berapa besar pengaruh pembiayaan yang disalurkan oleh BUS dan UUS berdasarkan lapangan usaha pengangkutan, pergudangan, dan komunikasi terhadap Produk Domestik Bruto Indonesia berdasarkan lapangan usaha pengangkutan, pergudangan, dan komunikasi?

5. Adakah hubungan, kontribusi serta berapa besar pengaruh pembiayaan yang disalurkan oleh BUS dan UUS berdasarkan lapangan usaha jasa dunia usaha terhadap Produk Domestik Bruto Indonesia berdasarkan lapangan usaha jasa dunia usaha?

6. Adakah hubungan, kontribusi serta berapa besar pengaruh pembiayaan yang disalurkan oleh BUS dan UUS berdasarkan lapangan usaha jasa sosial masyarakat terhadap Produk Domestik Bruto Indonesia berdasarkan lapangan usaha jasa sosial masyarakat?

7. Adakah hubungan, kontribusi serta berapa besar pengaruh pembiayaan yang disalurkan oleh BUS dan UUS berdasarkan lapangan usaha jasa lainnya terhadap Produk Domestik Bruto Indonesia berdasarkan lapangan usaha jasa lainnya?

\section{Kajian Pustaka}

\subsection{Landasan Teori}

\subsubsection{Bank Syariah}

Berdasarkan UU No. 21 tahun 2008 tentang Perbankan Syariah, Bank Syariah adalah bank yang menjalankan seluruh kegiatannya berdasarkan prinsip syariah atau prinsip hukum Islam dan telah diatur dalam fatwa Majelis Ulama Indonesia (Andrianto \& Firmansyah, 2019)

\subsubsection{Pembiayaan Bank Syariah}

\subsubsection{Pengertian Pembiayaan Bank Syariah}

Berdasarkan UU No. 10 tahun 1998 tentang perbankan menyatakan pembiayaan berdasarkan prinsip syariah adalah penyediaan uang atau tagihan yang dipersamakan dengan itu berdasarkan persetujuan atau kesepakatan antara bank dengan pihak lain yang mewajibkan pihak yang dibiayai untuk mengembalikan uang atau tagihan tersebut setelah jangka waktu tertentu dengan imbalan 
atau bagi hasil (Andrianto \& Firmansyah, 2019).

\subsubsection{Tujuan dan Fungsi Pembiayaan Bank Syariah}

\section{1) Tujuan Pembiayaan Bank Syariah}

Tujuan pembiayaan bank syariah secara makro adalah sebagai berikut:

- Peningkatan ekonomi umat

- Meningkatkan produktivitas

- Tersedianya dana bagi peningkatan usaha

- Membuka lapangan kerja baru

- Terjadinya distribusi pendapatan

Sedangkan tujuan pembiayaan bank syairah secara mikro adalah sebagai berikut:

- Upaya memaksimalkan laba

- Upaya meminimalkan resiko

- Pendayagunaan sumber ekonomi
- Penyaluran kelebihan dana

- Menghindari terjadinya dana menganggur

\section{2) Fungsi Pembiayaan Bank Syariah}

- Memberikan pembiayaan dengan prinsip syariah yang menerapkan sistem bagi hasil yang tidak memberatkan debitur.

- Membantu kaum dhuafa yang tidak tersentuh oleh bank konvensional karena tidak mampu memenuhi persyaratan yang ditetapkan oleh bank konvensional.

- Membantu masyarakat ekonomi lemah yang selalu dipermainkan oleh rentenir dengan membantu melalui pendanaan untuk usaha yang dilakukan.

\subsubsection{Jenis-Jenis Pembiayaan Bank Syariah}

a. Berdasarkan Penggunaan: pembiayaan konsumtif (pembiayaan perumahan, pembiayaan mobil, pembiayaan multiguna, kartu pembiayaan), pembiayaan komersial (pembiayaan mikro, pembiayaan usaha kecil, pembiayaan usaha menengah, pembiayaan korporasi).

b. Berdasarkan Keperluan: pembiayaan modal kerja, pembiayaan investasi, pembiayaan proyek.

c. Berdasarkan Cara Penarikan: sekaligus, bertahap, rekening koran (revolving) atau penarikan sesuai kebutuhan.

d. Berdasarkan Metode Pembiayaan: pembiayaan bilateral, pembiayaan sindikasi.

e. Berdasarkan Jangka Waktu: pembiayaan jangka pendek, pembiayaan jangka menengah, pembiayaan jangka panjang.

f. Berdasarkan Perjanjian atau Akad Pembiayaan: pembiayaan berdasarkan perjanjian jual beli, pembiayaan berdasarkan perjanjian transaksi penanaman modal, pembiayaan berdasarkan pernjanjian transaksi pinjam-meminjam.

\subsubsection{Akad-Akad Pembiayaan Bank Syariah}
1. Mudharabah
2. Musyarakah
4. Istishna
3. Salam
5. Ijarah
6. Qardh

\subsubsection{Produk Domestik Bruto}

Produk Domestik Bruto menurut merupakan nilai keseluruhan semua barang dan jasa yang diproduksi di dalam wilayah tersebut dalam jangkat waku tertentu, biasanya per tahun (Atika, 2018). Produk Domestik Bruto terdiri dari Produk Domestik Bruto atas dasar harga berlaku yang merupakan gambaran nilai tambah barang dan jasa dihitung dari harga berlaku setiap tahun, dan Produk Domestik Bruto atas dasar harga konstan yang menunjukkan nilai tambah barang dan jasa dan dihitung menggunakan harga yang berlaku pada satu tahun tertentu (Tripuspitorini \& Setiawan, 2020). Data Produk Domestik Bruto dapat diturunkan menjadi beberapa indikator ekonomi 
lainnya, seperti:

1) Produk Nasional Bruto

2) Produk Nasional Neto atas dasar harga pasar

3) Produk Nasional Neto atas dasar biaya faktor produksi

4) Angka-Angka Per Kapita

\subsubsection{Sektor-Sektor Ekonomi Menurut Klasifikasi Baku Lapangan Usaha} Indonesia (KBLI) Tahun 2017

1) Pertanian, Kehutanan, dan Perikanan

2) Pertambangan dan Penggalian

3) Industri Pengolahan

4) Pengadaan Listrik, Gas, Uap/Air Panas dan Udara Dingin

5) Pengelolaan Air, Pengelolaan Air Limbah, Pengelolaan dan Daur Ulang Sampah, dan Aktivitas Remediasi

6) Konstruksi

7) Perdagangan Besar dan Eceran, Reparasi dan Perawatan Mobil dan Sepeda Motor

8) Penyediaan Akomodasi dan Penyediaan Makan Minum

9) Informasi dan Komunikasi

10) Aktivitas Keuangan dan Asuransi

11) Real Estate

12) Aktivitas Profesional, Ilmiah, dan Teknis

13) Aktivitas Penyewaan dan Sewa Guna Usaha Tanpa Hak Opsi, Ketenagakerjaan, Agen Perjalanan dan Penunjang Usaha Lainnya

14) Administrasi Pemerintahan, Pertahanan dan Jaminan Sosial Wajib

15) Pendidikan

16) Aktivitas Kesehatan Manusia dan Aktivitas Sosial

17) Kesenian, Hiburan, dan Rekreasi

18) Aktivitas Jasa Lainnya

19) Aktivitas Rumah Tangga sebagai Pemberi Kerja; Aktivitas yang Menghasilkan Barang dan Jasa oleh Rumah Tangga yang Digunakan untuk Memenuhi Kebutuhan Sendiri

(sumber: Badan Pusat Statistik, 2017)

\subsubsection{Sektor- Sektor-Sektor Ekonomi Menurut Badan Pusat Statistik}

1) Pertanian, Kehutanan, dan Perikanan Minum

2) Pertambangan dan Penggalian

10) Informasi dan Komunikasi

3) Industri Pengolahan

4) Pengadaan Listrik dan Gas

5) Pengadaan Air, Pengelolaan Sampah, Limbah, dan Daur Ulang

6) Konstruksi

7) Perdagangan Besar dan Eceran; Reparasi Mobil dan Sepeda Motor

8) Transportasi dan Pergudangan

9) Penyediaan Akomodasi dan Makan

11) Jasa Keuangan dan Asuransi

12) Real Estate

13) Jasa Perusahaan

14) Administrasi Pemerintahan, Pertahanan, dan Jaminan Sosial Wajib

15) Jasa Pendidikan

16) Jasa Kesehatan dan Kegiatan Sosial

17) Jasa Lainnya

(sumber: Badan Pusat Statistik, 2017)

\subsection{Penelitian Terdahulu}

Menurut penelitian Nurlaili Adkhi Rizfa Faiza dengan judul Pengaruh Alokasi Pembiayaan Sektor-Sektor Ekonomi oleh Perbankan Syariah terhadap Produk Domestik Regional Bruto (PDRB) Provinsi Jawa Timur menunjukkan bahwa dari seluruh pembiayaan sektor ekonomi yang diteliti tidak seluruhnya memiliki pengaruh yang positif dan signifikan terhadap Produk Domestik Bruto Regional (PDRB) Jawa Timur (Faiza, 2017). Penelitian lain yang dilakukan oleh Imam Asngari yang berjudul Pengaruh Pembiayaan Bank Syariah Terhadap Pertumbuhan Ekonomi Indonesia memberikan hasil bahwa semakin tinggi pembiayaan yang disalurkan oleh Bank Syariah 
maka pertumbuhan ekonomi di Indonesia semakin meningkat (Asngari, 2015). Md Hakim Ali dan Md Akhter Uddin dalam penelitian yang berjudul Does Islamic Bank Financing Lead to Economic Growth? An Empirical Analysis for Malaysia mendapatkan hasil bahwa konstribusi keuangan Islam terhadap pertumbuhan ekonomi lemah. Produk Domestik Bruto bukan tergantung pada keuangan Islam (Bm \& Uddin, 2016). Berbeda lagi dengan penelitian Baaeth Atallah Aldalaien yang berjudul The Impact of Islamic Banks on the Gross Domestic Product (GDP): An Empirical Study in Dubai menyatakan hasil bahwa bank dan keuangan Islam dapat secara signifikan meningkatkan Produk Domestik Bruto Uni Emirat Arab dan Dubai pada khususnya (Aldalaien, 2019).

\subsection{Kerangka Pemikiran}

Kerangka pemikiran merupakan uraian tentang bagaimana peneliti mengalirkan jalan pikiran dengan logis untuk memecahkan masalah yang sudah dirumuskan (Suryana, 2010).

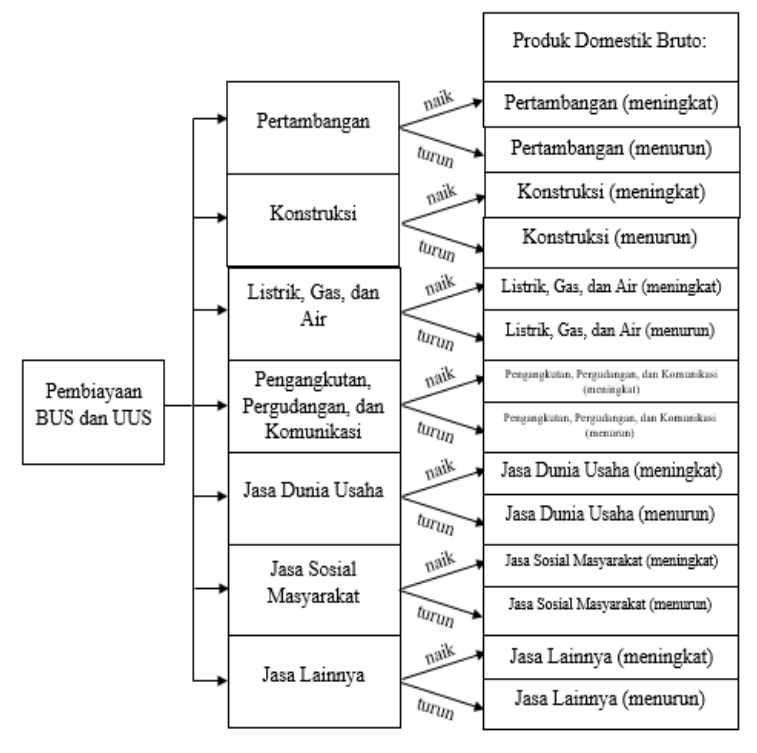

Sumber: diolah sendiri

Gambar 3. Kerangka Pemikiran

\subsection{Hipotesis Penelitian}

a) Diduga terdapat hubungan, kontribusi, dan pengaruh positif dan signifikan pembiayaan berdasarkan lapangan usaha pertambangan terhadap Produk Domestik Bruto berdasarkan lapangan usaha pertambangan.

b) Diduga terdapat hubungan, kontribusi, dan pengaruh positif dan signifikan pembiayaan berdasarkan lapangan usaha konstruksi terhadap Produk Domestik Bruto berdasarkan lapangan usaha konstruksi.

c) Diduga terdapat hubungan, kontribusi, dan pengaruh positif dan signifikan pembiayaan berdasarkan lapangan usaha konstruksi terhadap Produk Domestik Bruto berdasarkan lapangan usaha listrik, gas, dan air.

d) Diduga terdapat hubungan, kontribusi, dan pengaruh positif dan signifikan pembiayaan berdasarkan lapangan usaha pengangkutan, pergudangan, dan komunikasi terhadap Produk Domestik Bruto berdasarkan lapangan usaha pengangkutan, pergudangan, dan komunikasi.

e) Diduga terdapat hubungan, kontribusi, dan pengaruh positif dan signifikan pembiayaan berdasarkan lapangan usaha jasa dunia usaha terhadap Produk Domestik Bruto berdasarkan lapangan usaha jasa dunia usaha.

f) Diduga terdapat hubungan, kontribusi, dan pengaruh positif dan signifikan pembiayaan berdasarkan lapangan usaha jasa sosial masyarakat terhadap Produk Domestik Bruto 
berdasarkan lapangan usaha jasa sosial masyarakat.

g) Diduga terdapat hubungan, kontribusi, dan pengaruh positif dan signifikan pembiayaan berdasarkan lapangan usaha jasa lainnya terhadap Produk Domestik Bruto berdasarkan lapangan usaha jasa lainnya.

\section{Metode Penelitian}

\subsection{Metode Penelitian yang Digunakan}

Penelitian kuantitatif merupakan suatu metode penelitian yang berlandaskan pada filsafat positivisme, digunakan untuk meneliti padat populasi atau sampel tertentu, pengumpulan data menggunakan instrumen penelitian, analisis data bersifat kuantitatif/statistik, dengan tujuan untuk menguji hipotesis yang telah ditetapkan (Sugiyono, 2015). Metode Penelitian yang digunakan adalah penelitian deskriptif dengan pendekatan kuantitatif.

\subsection{Jenis dan Sumber Data}

Jenis data adalah data sekunder. Data berasal dari Statistik Perbankan Syariah dari Otoritas Jasa Keuangan dan Produk Domestik Bruto Indonesia dari Badan Pusat Statistik.

\subsection{Teknik Pengumpulan Data}

Tujuan pengumpulan data adalah untuk memecahkan masalah yang akan diteliti dan untuk menguji hipotesis yang telah dirumuskan. Penulis melakukan metode pengumpulan data yang dilakukan untuk memperoleh data dalam penelitian ini dengan studi kepustakaan. Studi Kepustakaan, merupakan salah satu cara pengumpulan data dengan mempelajari buku, jurnal ilmiah, skripsi, makalah, maupun situs website untuk memperoleh informasi yang dapat digunakan menjadi data dan berkaitan dengan masalah ataupun variabel yang digunakan, yakni pembiayaan BUS dan UUS berdasarkan lapangan usaha, dan Produk Domestik Bruto berdasarkan lapangan usaha dengan rentang waktu selama 8 tahun (2012-2019).

\subsection{Populasi dan Sampel}

Populasi dalam penelitian ini menggunakan data semua lapangan usaha yang dibiayai oleh BUS dan UUS berdasarkan lapangan usaha. Sampel dari penelitian ini adalah pengambilan data 7 lapangan usaha dari 10 sebanyak 8 tahun dibagi menjadi 32 data triwulan setiap lapangan usahanya.

Teknik pengambilan sampel yang digunakan dalam penelitian ini adalah purposive sampling yang merupakan teknik penentuan sampel dengan pertimbangan tertentu (Sugiyono, 2015). Dalam penelitian ini 7 lapangan usaha dari total 11 lapangan usaha akan diambil datanya dan diteliti dikarenakan terdapat perubahan naik turun pembiayaan dan dampaknya terhadap Produk Domestik Bruto Indonesia.

\subsection{Teknik Analisis Data}

Teknik analisa yang digunakan dalam penelitian ini adalah analisa kuantitatif yaitu analisa yang dilakukan melalui pengukuran dalam bentuk rangka-angka dengan metode statistik. Berikut adalah tahap-tahap dalam melakukan teknik analisis data dalam penelitian ini:

1. Uji Normalitas Data. Data yang sebaiknya dan layak digunakan adalah data yang memiliki distribusi normal. Dalam pengujian normalitas data ini digunakan dengan uji statistik Kolmogorov-Smirnov yang mana kaidah yang digunakan adalah skor Sig, dengan ketentuan apabila data memiliki nilai Sig. $>0,05$ maka data tersebut berdistribusi normal, sedangkan apabila data memiliki nilai Sig. $<0,05$ maka data tersebut berdistribusi tidak normal.

2. Korelasi dan Koefisien Determinasi. Korelasi bertujuan untuk menguji ada tidaknya hubungan serta arah dari dua variabel atau lebih. Korelasi dilambangkan dengan huruf R. Nilai $\mathrm{R}$ yang mendekati -1 dan 1 menunjukkan hubungan yang kuat antar dua variabel, sementara nilai $\mathrm{R}$ yang mendekati 0 menunjukkan lemahnya hubungan variabel tersebut. Arah hubungan korelasi terdiri 
dari arah hubungan positif, negatif, dan nihil (0). Koefisien determinasi bertujuan untuk menghitung berapa besar perubahan variasi variabel dependen dapat dijelaskan oleh variasi variabel independen. Jika $\mathrm{R} 2=0$, artinya variasi variabel independen tidak menjelaskan sedikitpun variasi variabel dependen. Jika R2 $=1$, artinya variasi variabel independen menjelaskan $100 \%$ variasi variabel dependen.

3. Regresi Linier Sederhana. Regresi bertujuan untuk menguji seberapa besar pengaruh antara variabel pembiayaan berdasarkan lapangan usaha terhadap Produk Domestik Bruto berdasarkan lapangan usaha. Persamaan yang digunakan adalah sebagai berikut:
1) $\mathrm{PDB}_{\mathrm{PRT}}=\beta_{0}+\beta \mathrm{P}_{\mathrm{PRT}}$
2) $\mathrm{PDB}_{\mathrm{KR}}=\beta_{0}+\beta \mathrm{P}_{\mathrm{KR}}$
3) $\mathrm{PDB}_{\mathrm{LGA}}=\beta_{0}+\beta \mathrm{P}_{\mathrm{LGA}}$
4) $\mathrm{PDB}_{\mathrm{PPK}}=\beta_{0}+\beta \mathrm{P}_{\mathrm{PPK}}$
5) $\mathrm{PDB}_{\mathrm{JDA}}=\beta_{0}+\beta \mathrm{P}_{\mathrm{JDA}}$
6) $\mathrm{PDB}_{\mathrm{JSM}}=\beta_{0}+\beta \mathrm{P}_{\mathrm{JSM}}$
7) $\mathrm{PDB}_{\mathrm{JL}}=\beta_{0}+\beta \mathrm{P}_{\mathrm{JL}}$

Keterangan:

$\mathrm{P}_{\mathrm{PRT}}=$ Pembiayaan berdasarkan lapangan usaha pertambangan

$\mathrm{P}_{\mathrm{KR}} \quad=$ Pembiayaan berdasarkan lapangan usaha konstruksi

$\mathrm{P}_{\mathrm{LGA}}=$ Pembiayaan berdasarkan lapangan usaha listrik, gas, dan air

$\mathrm{P}_{\mathrm{PPK}}=$ Pembiayaan berdasarkan lapangan usaha pengangkutan, pergudangan, dan komunikasi

$\mathrm{P}_{\mathrm{JDA}}=$ Pembiayaan berdasarkan lapangan usaha jasa dunia usaha

$\mathrm{P}_{\mathrm{JDM}}=$ Pembiayaan berdasarkan lapangan usaha jasa sosial masyarakat

$\mathrm{P}_{\mathrm{JL}} \quad=$ Pembiayaan berdasarkan lapangan usaha jasa lainnya

$\mathrm{PDB}_{\mathrm{PRT}}=$ Produk Domestik Bruto berdasarkan lapangan usaha pertambangan

$\mathrm{PDB}_{\mathrm{KR}}=$ Produk Domestik Bruto berdasarkan berdasarkan lapangan usaha konstruksi

$\mathrm{PDB}_{\mathrm{LGA}}=$ Produk Domestik Bruto berdasarkan lapangan usaha listrik, gas, dan air

$\mathrm{PDB}_{\mathrm{PPK}}=$ Produk Domestik Bruto berdasarkan lapangan usaha pengangkutan,pergudangan, dan komunikasi

$\mathrm{PDB}_{\mathrm{JDU}}=$ Produk Domestik Bruto berdasarkan lapangan usaha jasa dunia usaha

$\mathrm{PDB}_{\mathrm{JDM}}=$ Produk Domestik Bruto berdasarkan lapangan usaha jasa sosial masyarakat

$\mathrm{PDB}_{\mathrm{JL}} \quad=$ Produk Domestik Bruto berdasarkan lapangan usaha jasa lainnya

4. Uji Hipotesis. Tujuan pengujian ini adalah untuk mengetahui apakah ada pengaruh secara signifikan dari masing-masing variabel independen terhadap variabel dependen. Pengujian ini dilakukan dengan cara membandingkan t-hitung dengan t-tabel. Jika t-hitung tidak lebih besar dari t-tabel dan nilai signifikansi t $>0,05$ maka hipotesis tidak teruji dan tidak terdapat pengaruh signifikan. Tetapi jika t-hitung lebih besar dari t-tabel dan nilai signifikansi $t<0,05$ maka terdapat pengaruh signifikan. 


\section{Hasil dan Pembahasan}

\subsection{Lapangan Usaha Pertambangan}

Tabel 1. Uji Normalitas Data

One-Sample Kolmogorov-Smirnov Test

\begin{tabular}{|c|c|}
\hline & $\begin{array}{l}\text { Unstandardized } \\
\text { Predicted Value }\end{array}$ \\
\hline 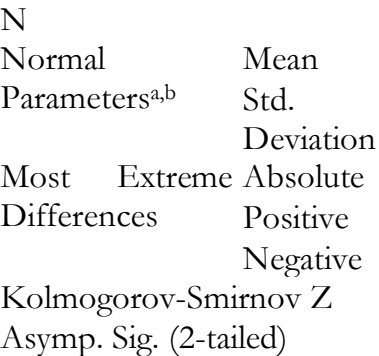 & $\begin{array}{l}32 \\
7,8517662 \mathrm{E} 5 \\
1,36189413 \mathrm{E} 3 \\
\\
, 174 \\
121 \\
-, 174 \\
493 \\
, 968\end{array}$ \\
\hline
\end{tabular}

a. Test distribution is Normal.

b. Calculated from data.
Berdasarkan uji normalitas, didapatkan hasil bahwa nilai Kolmogorov-Smirnov sebesar 0,493 dan asymp. Sig. (2-tailed) sebesar 0,968. Nilai tersebut lebih besar dari 0,05 sehingga data dapat dipastikan berdistribusi normal.

Tabel 2. Korelasi dan Koefisien Determinasi

Model Summary ${ }^{\mathrm{b}}$

\begin{tabular}{|c|c|c|c|c|}
\hline Model & $\mathrm{R}$ & $\begin{array}{l}\mathrm{R} \\
\text { Square }\end{array}$ & $\begin{array}{l}\text { Adjusted } \\
\text { R Square }\end{array}$ & $\begin{array}{l}\text { Std. Error } \\
\text { of the } \\
\text { Estimate }\end{array}$ \\
\hline dimension0 1 &, $099^{a}$ &, 010 &,- 155 & 14860,833 \\
\hline
\end{tabular}

a. Predictors: (Constant), Pembiayaan Pertambangan b. Dependent Variable: PDB Pertambangan
Menurut uji koefisien determinasi diketahui bahwa antara variabel pembiayaan dan variabel produk domestik bruto terdapat korelasi yang sangat lemah, ditunjukkan dengan nilai $\mathrm{R}$ sebesar 0,099. Variabel pembiayaan hanya mampu menjelaskan variabel PDB sebesar 1\% sisanya dijelaskan oleh hal lain yang tidak diteliti dalam penelitian ini.

Tabel 3. Regresi dan Uji t-test

Coefficients $^{\mathrm{a}}$

\begin{tabular}{|l|l|l|l|l|l|}
\hline Model & \multicolumn{2}{|l|}{$\begin{array}{l}\text { Unstandardized } \\
\text { Coefficients }\end{array}$} & $\begin{array}{l}\text { Standardized } \\
\text { Coefficients }\end{array}$ & & \\
\cline { 2 - 5 } & $\mathrm{B}$ & Std. Error & Beta & $\mathrm{t}$ & Sig. \\
\hline 1 (Constant) & 781493,451 & 16073,513 & & 48,620 &, 000 \\
Pembiayaan &, 064 &, 263 &, 099 &, 242 &, 816 \\
Pertambangan & & & & & \\
\hline
\end{tabular}

a. Dependent Variable: PDB Pertambangan
Berdasarkan tabel uji regresi dan uji ttest, dapat diketahui bahwa konstanta PDB $_{\text {PRT }}$ adalah sebesar 781.493,451 dan koefisien P $_{\text {PRT }}$ adalah sebesar 0,064. Hal ini menunjukkan bahwa pada saat $\mathrm{P}_{\mathrm{PRT}}=0$, maka nilai $\mathrm{PDB}_{\mathrm{PRT}}$ adalah 781.493,451. Dilihat dari nilai signifikansi sebesar 0,816 menunjukkan bahwa pengaruh tersebut tidak signifikan. Kemudian, setiap peningkatan 1\% pembiayaan akan meningkatkan PDB sebesar 64 juta rupiah. Nilai t-tabel adalah sebesar 2,446. Berdasarkan hasil yang didapatkan, dilihat dari nilai t-hitung sebesar 0,242 lebih kecil dari t-tabel dan nilai signifikansi sebesar 0,816 yang berarti bahwa variabel pembiayaan tidak berpengaruh signifikan terhadap PDB. 


\subsection{Lapangan Usaha Konstruksi}

Tabel 4. Uji Normalitas Data

One-Sample Kolmogorov-Smirnov Test

\begin{tabular}{|c|c|}
\hline & $\begin{array}{l}\text { Unstandardized } \\
\text { Predicted Value }\end{array}$ \\
\hline 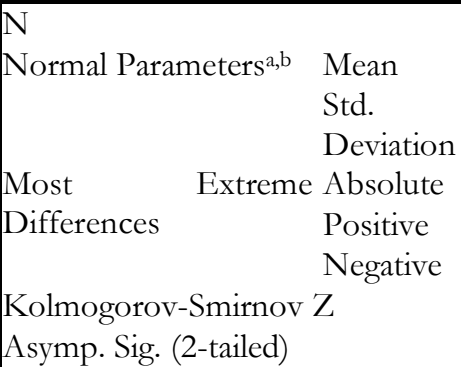 & $\begin{array}{l}32 \\
9,0952425 \mathrm{E} 5 \\
1,29046068 \mathrm{E} 5 \\
269 \\
, 269 \\
-, 142 \\
762 \\
608\end{array}$ \\
\hline
\end{tabular}

Berdasarkan uji normalitas variabel $P_{\mathrm{KR}}$, didapatkan hasil bahwa nilai Kolmogorov-Smirnov sebesar 0,762 dan asymp. Sig. (2-tailed) sebesar 0,608. Nilai tersebut lebih besar dari 0,05 sehingga data dapat dipastikan berdistribusi normal.

a. Test distribution is Normal.

b. Calculated from data.

Tabel 5. Korelasi dan Koefisien Determinasi

\begin{tabular}{|c|c|c|c|c|}
\hline \multicolumn{5}{|c|}{ Model Summary ${ }^{b}$} \\
\hline Model & $\mathrm{R}$ & $\begin{array}{l}\mathrm{R} \\
\text { Square }\end{array}$ & $\begin{array}{l}\text { Adjusted } \\
\text { R Square }\end{array}$ & $\begin{array}{l}\text { Std. Error } \\
\text { of the } \\
\text { Estimate }\end{array}$ \\
\hline dimension0 1 & ,968a &, 936 &, 925 & 36416,948 \\
\hline
\end{tabular}

a. Predictors: (Constant), Pembiayaan Konstruksi

b. Dependent Variable: PDB Konstruksi
Menurut uji koefisien determinasi diketahui bahwa antara variabel pembiayaan dan variabel produk domestik bruto terdapat korelasi yang sangat kuat, ditunjukkan dengan nilai $\mathrm{R}$ sebesar 0,968. Variabel pembiayaan mampu menjelaskan variabel PDB sebesar 93,6\% sisanya dijelaskan oleh hal lain yang tidak diteliti dalam penelitian ini.

Tabel 6. Regresi dan Uji t-test

\begin{tabular}{|l|l|l|l|l|l|}
\hline Model & \multicolumn{2}{|c|}{ Coefficients $^{\mathbf{a}}$} & & \\
& Coefficients & $\begin{array}{l}\text { Standardized } \\
\text { Coefficients }\end{array}$ & & \\
& B & Std. Error & Beta & t & Sig. \\
\hline 1 (Constant) & 667282,164 & 28868,285 & & 23,115 &, 000 \\
Pembiayaan & 1,395 &, 149 &, 968 & 9,375 &, 000 \\
Konstruksi & & & & & \\
\hline
\end{tabular}

a. Dependent Variable: PDB Konstruksi

Berdasarkan tabel uji regresi dan uji ttest, dapat diketahui bahwa konstanta PDB $_{\mathrm{KR}}$ adalah sebesar 667.282,164 dan koefisien $P_{K R}$ adalah sebesar 1.395. Hal ini menunjukkan bahwa pada saat $\mathrm{P}_{\mathrm{KR}}=0$, maka nilai $\mathrm{PDB}_{\mathrm{KR}}$ adalah 667.282,164. Dilihat dari nilai signifikansi sebesar 0,000 menunjukkan bahwa pengaruh tersebut signifikan. Kemudian, setiap peningkatan $1 \%$ pembiayaan akan meningkatkan PDB sebesar 1,39 miliar rupiah. Nilai t-tabel adalah sebesar 2,446. Berdasarkan hasil yang didapatkan, dilihat dari nilai t-hitung sebesar 9,375 lebih besar dari t-tabel dani nilai signifikansi 0,000 yang berarti bahwa variabel pembiayaan berpengaruh signifikan terhadap PDB. 


\subsection{Lapangan Usaha Listrik, Gas, dan Air}

Tabel 7. Uji Normalitas Data

One-Sample Kolmogorov-Smirnov Test

\begin{tabular}{|c|c|}
\hline & $\begin{array}{l}\text { Unstandardized } \\
\text { Predicted Value }\end{array}$ \\
\hline $\begin{array}{ll}\text { N } & \\
\text { Normal } & \text { Mean } \\
\text { Parameters }{ }^{\mathrm{a}, \mathrm{b}} & \text { Std. } \\
& \text { Deviation } \\
\text { Most Extreme } & \text { Absolute } \\
\text { Differences } & \text { Positive } \\
& \text { Negative } \\
& \text { Kolmogorov-Smirnov Z } \\
\text { Asymp. Sig. (2-tailed) }\end{array}$ & $\begin{array}{l}32 \\
1,0530075 \mathrm{E} 5 \\
9,57449584 \mathrm{E} 3 \\
\\
, 201 \\
, 201 \\
-, 159 \\
, 569 \\
, 902\end{array}$ \\
\hline
\end{tabular}

a. Test distribution is Normal.

b. Calculated from data.
Berdasarkan uji normalitas variabel $\mathrm{P}_{\mathrm{LGA}}$ didapatkan hasil bahwa nilai Kolmogorov-Smirnov sebesar 0,569 dan asymp. Sig. (2-tailed) sebesar 0,902. Nilai tersebut lebih besar dari 0,05 sehingga data dapat dipastikan berdistribusi normal.

Tabel 8. Korelasi dan Koefisien Determinasi

\begin{tabular}{|l|l|l|l|l|}
\hline Model & & Model Summary & \\
& R & $\begin{array}{l}\text { Adjusted } \\
\text { Square }\end{array}$ & $\begin{array}{l}\text { Std. Error } \\
\text { R Square }\end{array}$ \\
Estimate \\
\hline dimension0 1 &, $959^{\mathrm{a}}$ &, 920 &, 907 & 3040,659 \\
\hline
\end{tabular}

a. Predictors: (Constant), Pembiayaan Listrik, Gas, dan Air

b. Dependent Variable: PDB Listrik, Gas, dan Air
Menurut uji koefisien determinasi, diketahui bahwa antara variabel pembiayaan dengan variabel produk domestik bruto terdapat korelasi yang sangat kuat, ditunjukkan dengan nilai R sebesar 0,959. Variabel pembiayaan mampu menjelaskan variabel PDB sebesar $92 \%$ sisanya dijelaskan oleh hal lain yang tidak diteliti dalam penelitian ini.

Tabel 9. Regresi dan Uji t-test

\section{Coefficients $^{\mathrm{a}}$}

\begin{tabular}{|c|c|c|c|c|c|}
\hline \multirow[t]{2}{*}{ Model } & \multirow{2}{*}{$\begin{array}{l}\text { Unstandardized } \\
\text { Coefficients } \\
\text { B }\end{array}$} & \multicolumn{2}{|c|}{$\begin{array}{l}\text { Standardized } \\
\text { Coefficients }\end{array}$} & \multirow[b]{2}{*}{$\mathrm{t}$} & \\
\hline & & $\begin{array}{l}\text { Std. } \\
\text { Error }\end{array}$ & Beta & & Sig. \\
\hline 1 (Constant) & 88679,066 & 2266,355 & & 39,128 &, 000 \\
\hline $\begin{array}{l}\text { Pembiayaan } \\
\text { Listrik, Gas, } \\
\text { dan Air }\end{array}$ &, 180 &, 022 &, 959 & 8,331 &, 000 \\
\hline
\end{tabular}

a. Dependent Variable: PDB Listrik, Gas, dan Air
Berdasarkan tabel uji regresi dan uji t-test, dapat diketahui bahwa konstanta $\mathrm{PDB}_{\mathrm{LGA}}$ adalah sebesar 88.679,066 dan koefisien $\mathrm{P}_{\mathrm{LGA}}$ adalah sebesar 0,180 . Hal ini menunjukkan bahwa pada saat $\mathrm{P}_{\mathrm{LGA}}=0$, maka nilai $\mathrm{PDB}_{\mathrm{LGA}}$ adalah 88.679,066. Dilihat dari nilai signifikansi sebesar 0,000 menunjukkan bahwa pengaruh tersebut signifikan. Kemudian, setiap peningkatan $1 \%$

pembiayaan akan meningkatkan PDB sebesar 180 juta rupiah. Rumus persamaan yang diperoleh dari variabel $P_{L G A}$ terhadap variabel $P_{D B} B_{L G A}$ adalah sebagai berikut: Nilai t-tabel adalah sebesar 2,446. Dilihat dari nilai t-hitung sebesar 8,331 lebih besar dari t-tabel dan signifikansi 0,000 yang berarti bahwa variabel pembiayaan lapangan usaha listrik, gas, dan air berpengaruh signifikan terhadap PDB lapangan usaha listrik, gas, dan air. 


\subsection{Lapangan Usaha Pengangkutan, Pergudangan, dan Komunikasi}

Tabel 10. Uji Normalitas Data

One-Sample Kolmogorov-Smirnov Test

\begin{tabular}{|c|c|c|}
\hline & & \begin{tabular}{|l} 
Unstandardized \\
Predicted Value
\end{tabular} \\
\hline \multirow{3}{*}{$\begin{array}{l}\text { N } \\
\text { Normal Parameters }\end{array}$} & & 32 \\
\hline & Mean & $8,1310362 \mathrm{E} 5$ \\
\hline & $\begin{array}{l}\text { Std. } \\
\text { Deviation }\end{array}$ & $7,74657176 \mathrm{E} 4$ \\
\hline Extreme & Absolute & 262 \\
\hline \multirow[t]{2}{*}{ Differences } & Positive &, 143 \\
\hline & Negative &,- 262 \\
\hline \multicolumn{2}{|l|}{ Kolmogorov-Smirnov Z } &, 740 \\
\hline \multicolumn{2}{|l|}{ Asymp. Sig. (2-tailed) } &, 644 \\
\hline
\end{tabular}

Berdasarkan uji normalitas variabel $\mathrm{P}_{\mathrm{PPK}}$ didapatkan hasil bahwa nilai Kolmogorov-Smirnov sebesar 0,740 dan asymp. Sig. (2-tailed) sebesar 0,644 . Nilai tersebut lebih besar dari 0,05 sehingga data dapat dipastikan berdistribusi normal.

a. Test distribution is Normal.

b. Calculated from data.

Tabel 11. Korelasi dan Koefisien Determinasi

Model Summary

\begin{tabular}{|l|l|l|l|l|}
\hline Model & R & $\begin{array}{l}\mathrm{R} \\
\text { Square }\end{array}$ & $\begin{array}{l}\text { Adjusted } \\
\mathrm{R} \text { Square }\end{array}$ & $\begin{array}{l}\text { Std. Error of } \\
\text { the Estimate }\end{array}$ \\
\hline dimension0 1 &, $488^{\mathrm{a}}$ &, 238 &, 111 & 149602,604 \\
\hline
\end{tabular}

a. Predictors: (Constant), Pembiayaan Pengangkutan, Perdagangan, dan Komunikasi

b. Dependent Variable: PDB Pengangkutan, Pergudangan, dan Komunikasi
Menurut uji koefisien determinasi, diketahui bahwa antara variabel pembiayaan dengan variabel produk domestik bruto terdapat korelasi yang cukup lemah, ditunjukkan dengan nilai $R$ sebesar 0,488. Variabel pembiayaan mampu menjelaskan variabel PDB sebesar 23,8\% sisanya dijelaskan oleh hal lain yang tidak diteliti dalam penelitian ini.

Tabel 12. Regresi dan Uji t-test

\begin{tabular}{|c|c|c|c|c|c|}
\hline \multicolumn{6}{|c|}{ Coefficients $^{\mathrm{a}}$} \\
\hline \multirow[t]{2}{*}{ Model } & \multicolumn{2}{|c|}{$\begin{array}{l}\text { Unstandardized } \\
\text { Coefficients }\end{array}$} & $\begin{array}{l}\text { Standardized } \\
\text { Coefficients }\end{array}$ & & \\
\hline & B & Std. Error & Beta & $\mathrm{t}$ & Sig. \\
\hline 1 (Constant) & 580011,258 & 178172,757 & & 3,255 &, 017 \\
\hline $\begin{array}{l}\text { Pembiayaan } \\
\text { Pengangkutan, } \\
\text { Perdagangan, } \\
\text { dan } \\
\text { Komunikasi }\end{array}$ & 2,127 & 1,553 &, 488 & 1,370 &, 220 \\
\hline
\end{tabular}

Berdasarkan tabel uji regresi dan uji ttest, dapat diketahui bahwa konstanta PDB $_{\text {PPK }}$ adalah sebesar 580.011,258 dan koefisien $\mathrm{P}_{\mathrm{PPK}}$ adalah sebesar 2.127. Hal ini menunjukkan bahwa pada saat $\mathrm{P}_{\mathrm{PPK}}=0$, maka nilai $\mathrm{PDB}_{\mathrm{PPK}}$ adalah 580.011,258. Dilihat dari nilai signifikansi sebesar $\quad 0,220$ menunjukkan bahwa pengaruh tersebut tidak signifikan. Kemudian, setiap peningkatan 1\% pembiayaan akan meningkatkan PDB 2,12 miliar rupiah. Nilai t-tabel adalah sebesar 2,446. Dilihat dari nilai t-hitung sebesar 1,370 lebih kecil dari t-tabel dan signifikansi 0,220 yang berarti bahwa variabel pembiayaan tidak berpengaruh signifikan terhadap PDB. 


\subsection{Lapangan Usaha Jasa Dunia Usaha}

Tabel 13. Uji Normalitas Data

\section{One-Sample Kolmogorov-Smirnov Test}

\begin{tabular}{|c|c|c|}
\hline & & $\begin{array}{l}\text { Unstandardized } \\
\text { Predicted Value }\end{array}$ \\
\hline \multicolumn{2}{|l|}{$\mathrm{N}$} & 32 \\
\hline \multirow[t]{3}{*}{ Normal Parameters } & Mean & 7,9093650E5 \\
\hline & Std. & $8,25701029 \mathrm{E} 4$ \\
\hline & Deviation & \\
\hline \multirow{3}{*}{$\begin{array}{l}\text { Diffest } \\
\text { Diffences }\end{array}$} & Absolute & 228 \\
\hline & Positive & 171 \\
\hline & Negative &,- 228 \\
\hline \multirow{2}{*}{\multicolumn{2}{|c|}{ Kolmogorov-Smirnov Z }} &, 646 \\
\hline & & ,798 \\
\hline
\end{tabular}

a. Test distribution is Normal.

b. Calculated from data.
Berdasarkan uji normalitas variabel $\mathrm{P}_{\mathrm{JDA}}$ didapatkan hasil bahwa nilai KolmogorovSmirnov sebesar 0,646 dan asymp. Sig. (2-tailed) sebesar 0,798. Nilai tersebut lebih besar dari 0,05 sehingga data dapat dipastikan berdistribusi normal.

\section{Tabel 14. Korelasi dan Koefisien Determinasi}

Model Summary

\begin{tabular}{|l|l|l|l|l|}
\hline Model & R & $\begin{array}{l}\text { R } \\
\text { Square }\end{array}$ & $\begin{array}{l}\text { Adjusted } \\
\text { R Square }\end{array}$ & $\begin{array}{l}\text { Std. Error of } \\
\text { the Estimate }\end{array}$ \\
\hline dimension0 1 &, $703^{\mathrm{a}}$ &, 495 &, 410 & 90172,06236 \\
\hline
\end{tabular}

a. Predictors: (Constant), Pembiayaan Jasa Dunia Usaha

b. Dependent Variable: PDB Jasa Dunia Usaha
Menurut uji koefisien determinasi, diketahui bahwa antara variabel pembiayaan dengan variabel produk domestik bruto terdapat korelasi yang cukup kuat, ditunjukkan dengan nilai $\mathrm{R}$ sebesar 0,703 . Variabel pembiayaan mampu menjelaskan variabel PDB sebesar 49,5\% sisanya dijelaskan oleh hal lain yang tidak diteliti dalam penelitian ini.

Tabel 15. Regresi dan Uji t-test

\section{Coefficients $^{\mathrm{a}}$}

\begin{tabular}{|l|l|l|l|l|l|}
\hline Model & \multicolumn{2}{|l|}{$\begin{array}{l}\text { Unstandardized } \\
\text { Coefficients }\end{array}$} & $\begin{array}{l}\text { Standardized } \\
\text { Coefficients }\end{array}$ & & \\
\cline { 2 - 5 } & $\mathrm{B}$ & Std. Error & Beta & $\mathrm{t}$ & Sig. \\
\hline 1 (Constant) & 938469,206 & 68736,401 & & 13,653 &, 000 \\
Pembiayaan &,- 414 &, 171 &,- 703 & $-2,423$ &, 052 \\
$\begin{array}{l}\text { Jasa Dunia } \\
\text { Usaha }\end{array}$ & & & & & \\
\hline
\end{tabular}

a. Dependent Variable: PDB Jasa Dunia Usaha
Berdasarkan tabel uji regresi dan uji ttest, dapat diketahui bahwa konstanta PDB $_{\text {JDA }}$ adalah sebesar 938.469,206 dan koefisien $\mathrm{P}_{J D A}$ adalah sebesar -0,414 . Hal ini menunjukkan bahwa pada saat $\mathrm{P}_{\text {JDA }}=0$, maka nilai $\mathrm{PDB}_{\text {IDA }}$ adalah 938.469,206. Dilihat dari nilai signifikansi sebesar 0,056 menunjukkan bahwa pengaruh tersebut sedikit tidak signifikan. Kemudian, setiap peningkatan 1\% pembiayaan akan menurunkan PDB sebesar 414 juta rupiah. Nilai t-tabel adalah sebesar 2,446. Dilihat dari nilai t-hitung sebesar -2,423 lebih kecil dari ttabel dan signifikansi 0,052 yang berarti bahwa variabel pembiayaan tidak berpengaruh signifikan terhadap PDB. 


\subsection{Lapangan Usaha Jasa Sosial Masyarakat}

Tabel 16. Uji Normalitas Data

One-Sample Kolmogorov-Smirnov Test

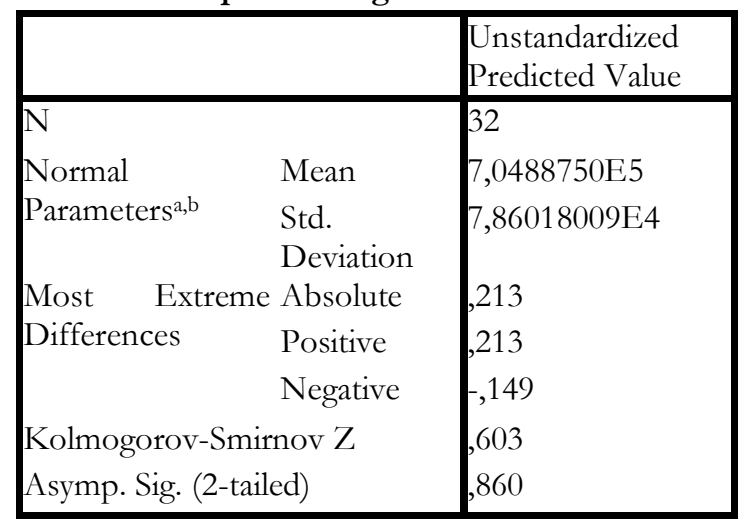

Berdasarkan uji normalitas variabel $\mathrm{P}_{\mathrm{JSM}}$, didapatkan hasil bahwa nilai Kolmogorov-Smirnov sebesar 0,604 dan asymp. Sig. (2-tailed) sebesar 0,860. Nilai tersebut lebih besar dari 0,05 sehingga data dapat dipastikan berdistribusi normal.

a. Test distribution is Normal.

b. Calculated from data.

Tabel 17. Korelasi dan Koefisien Determinasi

\begin{tabular}{|c|c|c|c|c|}
\hline \multicolumn{5}{|c|}{ Model Summary ${ }^{b}$} \\
\hline Model & $\mathrm{R}$ & \begin{tabular}{|l}
$\mathrm{R}$ \\
Square
\end{tabular} & $\begin{array}{l}\text { Adjusted } \\
\text { R Square }\end{array}$ & $\begin{array}{lr}\text { Std. Error } \\
\text { of } \\
\text { Estimate }\end{array}$ \\
\hline dimension0 1 &, $958^{a}$ &, 917 &, 904 & 25478,353 \\
\hline
\end{tabular}

Menurut uji koefisien determinasi, diketahui bahwa antara variabel pembiayaan dengan variabel produk domestik bruto terdapat korelasi yang sangat kuat, ditunjukkan dengan nilai $\mathrm{R}$ sebesar 0,958. Variabel pembiayaan mampu menjelaskan variabel PDB sebesar $91,7 \%$ sisanya dijelaskan oleh hal lain yang tidak diteliti dalam penelitian ini.

Tabel 18. Regresi dan Uji t-test

\section{Coefficients $^{\mathrm{a}}$}

\begin{tabular}{|c|c|c|c|c|c|}
\hline \multirow[t]{2}{*}{ Model } & \multicolumn{2}{|c|}{$\begin{array}{l}\text { Unstandardized } \\
\text { Coefficients }\end{array}$} & \multirow{2}{*}{\begin{tabular}{|l} 
Standardized \\
Coefficients \\
Beta \\
\end{tabular}} & \multirow[b]{2}{*}{$\mathrm{t}$} & \multirow[b]{2}{*}{ Sig. } \\
\hline & B & Std. Error & & & \\
\hline 1 (Constant) & 448156,399 & 32717,930 & & 13,698 &, 000 \\
\hline $\begin{array}{l}\text { Pembiayaan } \\
\text { Jasa Sosial } \\
\text { Masyarakat }\end{array}$ & 1,825 &, 224 & ,958 & 8,162 &, 000 \\
\hline
\end{tabular}

a. Dependent Variable: PDB Jasa Sosial Masyarakat

Berdasarkan tabel uji regresi dan uji t-test, dapat diketahui bahwa konstanta $\mathrm{PDB}_{\text {JSM }}$ adalah sebesar 448.156,399 dan koefisien $\mathrm{P}_{\mathrm{JSM}}$ adalah sebesar 1.825. Hal ini menunjukkan bahwa pada saat $\mathrm{P}_{\mathrm{JSM}}=0$, maka nilai $\mathrm{PDB}_{\mathrm{JSM}}$ adalah 448.156,399. Dilihat dari nilai signifikansi sebesar $\quad 0,000$ menunjukkan bahwa pengaruh tersebut signifikan. Kemudian, setiap peningkatan $1 \%$ pembiayaan akan meningkatkan PDB sebesar 1,82 miliar rupiah. Nilai t-tabel adalah sebesar 2,446. Dilihat dari nilai t-hitung sebesar 8,162 lebih besar dari t-tabel dan signifikansi sebesar 0,000 yang berarti bahwa variabel pembiayaan berpengaruh signifikan terhadap PDB. 


\subsection{Lapangan Usaha Jasa Lainnya}

Tabel 19. Uji Normalitas Data

One-Sample Kolmogorov-Smirnov Test

\begin{tabular}{|ll|l|}
\hline & & $\begin{array}{l}\text { Unstandardized } \\
\text { Predicted Value }\end{array}$ \\
\hline N & 8 \\
Normal & Mean & $1,5436012 \mathrm{E} 5$ \\
Parameters, & Std. & $2,45913997 \mathrm{E} 4$ \\
& Deviation & \\
Most Extreme & Absolute &, 369 \\
Differences & Positive &, 233 \\
& Negative &,- 369 \\
Kolmogorov-Smirnov Z & 1,044 \\
Asymp. Sig. (2-tailed) &, 226 \\
\hline
\end{tabular}

a. Test distribution is Normal.

b. Calculated from data.
Berdasarkan uji normalitas variabel $\mathrm{P}_{\mathrm{jl}}$ didapatkan hasil bahwa nilai Kolmogorov-Smirnov sebesar 1,044 dan asymp. Sig. (2-tailed) sebesar 0,226 Nilai tersebut lebih besar dari 0,05 sehingga data dapat dipastikan berdistribusi normal.

Tabel 20. Korelasi dan Koefisien Determinasi

\begin{tabular}{|c|c|c|c|c|}
\hline \multicolumn{5}{|c|}{ Model Summaryb } \\
\hline Model & $\mathrm{R}$ & $\begin{array}{l}\mathrm{R} \\
\text { Square }\end{array}$ & $\begin{array}{l}\text { Adjusted } \\
\text { R Square }\end{array}$ & $\begin{array}{l}\text { Std. Error } \\
\text { of the } \\
\text { Estimate }\end{array}$ \\
\hline dimension0 1 & ,791a &, 626 &, 564 & 20531,772 \\
\hline
\end{tabular}

a. Predictors: (Constant), Pembiayaan Jasa Lainnya b. Dependent Variable: PDB Jasa Lainnya
Menurut uji koefisien determinasi, diketahui bahwa antara variabel pembiayaan dengan variabel produk domestik bruto terdapat korelasi yang cukup kuat, ditunjukkan dengan nilai $\mathrm{R}$ sebesar 0,791 . Variabel pembiayaan mampu menjelaskan variabel PDB sebesar $62,6 \%$ sisanya dijelaskan oleh hal lain yang tidak diteliti dalam penelitian ini.

Tabel 21. Regresi dan Uji t-test

\begin{tabular}{|c|c|c|c|c|c|}
\hline \multicolumn{6}{|c|}{ Coefficients $^{a}$} \\
\hline \multirow[t]{2}{*}{ Model } & $\begin{array}{l}\text { Unstandardi } \\
\text { Coefficients }\end{array}$ & & $\begin{array}{l}\text { Standardized } \\
\text { Coefficients }\end{array}$ & & \\
\hline & B & \begin{tabular}{|l|} 
Std. \\
Error
\end{tabular} & Beta & $\mathrm{t}$ & Sig. \\
\hline 1 (Constant) & 172995,634 & 9342,262 & & 18,518 &, 000 \\
\hline $\begin{array}{l}\text { Pembiayaan } \\
\text { Jasa Lainnya }\end{array}$ &,- 065 &, 020 &,- 791 & $-3,169$ &, 019 \\
\hline
\end{tabular}

Berdasarkan tabel uji regresi dan uji ttest, dapat diketahui bahwa konstanta $\mathrm{PDB}_{\mathrm{JL}}$ adalah sebesar 172.995,634 dan koefisien $\mathrm{P}_{\mathrm{JL}}$ adalah sebesar 0,065. Hal ini menunjukkan bahwa pada saat $\mathrm{P}_{\mathrm{JL}}=0$, maka nilai $\mathrm{PDB}_{\mathrm{JL}}$ adalah 172.995,634. Dilihat dari nilai signifikansi sebesar $\quad 0,019$ menunjukkan bahwa pengaruh tersebut sedikit tidak signifikan. Kemudian, setiap peningkatan $1 \%$ pembiayaan akan menurunkan PDB sebesar 65 juta rupiah. Nilai t-tabel adalah sebesar 2,446. Dilihat dari nilai t-hitung sebesar 3,169 lebih kecil dari t-tabel dan signifikansi sebesar 0,019 yang berarti bahwa variabel pembiayaan berpengaruh sedikit tidak signifikan terhadap PDB.

\section{Penutup}

\subsection{Kesimpulan}

Dari hasil analisis penelitian yang telah dijelaskan sebelumnya dapat ditarik kesimpulan sebagai berikut:

- Pembiayaan BUS dan UUS lapangan usaha pertambangan memiliki hubungan yang sangat lemah, berkontribusi sangat kecil serta pengaruh yang positif dan tidak signifikan terhadap Produk Domestik Bruto Indonesia berdasarkan lapangan usaha pertambangan. 
- Pembiayaan BUS dan UUS lapangan usaha konstruksi memiliki hubungan yang sangat kuat, berkontribusi sangat besar serta pengaruh yang positif dan signifikan terhadap Produk Domestik Bruto Indonesia berdasarkan lapangan usaha konstruksi.

- Pembiayaan BUS dan UUS lapangan usaha listrik, gas, dan air memiliki hubungan yang sangat kuat, berkontribusi sangat besar serta pengaruh yang positif dan signifikan terhadap Produk Domestik Bruto Indonesia berdasarkan lapangan usaha listrik, gas, dan air.

- Pembiayaan BUS dan UUS lapangan usaha pengangkutan, pergudangan, dan komunikasi memiliki hubungan yang cukup lemah, berkontribusi kecil, serta pengaruh yang positif dan tidak signifikan terhadap Produk Domestik Bruto Indonesia berdasarkan lapangan usaha pengangkutan, pergudangan, dan komunikasi.

- Pembiayaan BUS dan UUS lapangan usaha jasa dunia usaha memiliki hubungan yang cukup kuat, berkontribusi cukup kecil serta pengaruh yang negatif dan sedikit tidak signifikan terhadap Produk Domestik Bruto Indonesia berdasarkan lapangan usaha jasa dunia usaha.

- Pembiayaan BUS dan UUS lapangan usaha jasa sosial masyarakat memiliki hubungan yang sangat besar, berkontribusi sangat kuat serta pengaruh yang positif dan signifikan terhadap Produk Bruto Indonesia berdasarkan lapangan usaha jasa sosial masyarakat.

- Pembiayaan BUS dan UUS lapangan usaha jasa lainnya memiliki hubungan yang cukup kuat, berkontribusi cukup besar serta pengaruh yang negatif dan sedikit tidak signifikan terhadap Produk Domestik Bruto Indonesia berdasarkan lapangan usaha jasa lainnya.

\subsection{Saran}

Berdasarkan hasil analisis data yang telah dipaparkan sebelumnya, terdapat beberapa saran yang dapat penulis sampaikan yaitu sebagai berikut:

1. BUS dan UUS dapat menambahkan jumlah pembiayaan syariah yang disalurkan berdasarkan lapangan usaha kontruksi; listrik, gas, dan air; serta jasa sosial/masyarakat karena pembiayaan berdasarkan lapangan usaha tersebut mampu untuk mendongkrak peningkatan Produk Domestik Bruto.

2. Upaya peningkatan Produk Domestik Bruto terhadap lapangan usaha pertambangan; pengangkutan, pergudangan, dan komunikasi; jasa dunia usaha; dan jasa lainnya dapat dilakukan melalui metode lain seperti kegiatan ekspor keluar negeri, pembiayaan investasi, pembiayaan konsumsi, dan lain sebagainya karena pembiayaan BUS dan UUS berdasarkan lapangan usaha tersebut tidak memiliki pengaruh yang kuat dalam meningkatkan Produk Domestik Bruto. Terdapat faktor lain yang dapat meningkatkan pertumbuhan Produk Domestik Bruto diluar pembiayaan BUS dan UUS.

3. Untuk penelitian selanjutnya dapat menambahkan variabel lainnya disamping pembiayaan BUS dan UUS untuk mengetahui faktor apa saja yang dapat meningkatkan atau berpengaruh terhadap Produk Domestik Bruto Indonesia.

\section{Daftar Pustaka}

Aldalaien, B. A. (2019). The Impact of Islamic Banks on the Gross Domestic Product (GDP): An Empirical Study in Dubai. 14(4), 135-142. https://doi.org/10.5539/ijbm.v14n4p135

Andrianto, \& Firmansyah, M. A. (2019). Buku Manajemen Bank Syariah (Q. Media (ed.); Cetakan Pe, Issue September). CV. Penerbit Qiara Media.

Anisa, L. S., \& Tripuspitorini, F. A. (2019). Analisis pengaruh dana pihak ketiga, non performing finance murabahah, dan inflasi terhadap pembiayaan murabahah pada bank. Jurnal Maps (Manajemen Perbankan Syariab), 52-64.

Apriyanthi, R., Purbayati, R., \& Setiawan. (2020). Faktor-Faktor yang Mempengaruhi Pembiayaan Sektor Konstruksi pada Perbankan Syariah di Indonesia. ProBank: Jurnal Ekonomi Dan 
Perbankan ISSN : $2579-5597$ (online) ISSN : 2252-7885 (cetak) ProBank: Jurnal Ekonomi Dan Perbankan ISSN : 2252-7885 (cetak). 5(1), 25-35.

Asngari, I. (2015). Pengarub Pembiayaan Bank Syariab Terbadap Pertumbuhan Ekonomi Indonesia (Vol. 54).

Atika. (2018). Pengarub Pembiayaan Dan Tingkat Bagi Hasil Terbadap Tingkat Kesejabteraan Di Indonesia Dilihat Dari Pertumbuhan PDB. 3(1), 49-57.

Badan Pusat Statistik. (2017). Klasifikasi Baku Lapangan Usaba Indonesia.

Badan Pusat Statistik Indonesia. (n.d.). PDB Triwulanan Atas Dasar Harga Konstan 2010 Menurut Lapangan Usaha (Miliar Rupiah) 2010-2019. Badan Pusat Statistik Indonesia.

Bm, H., \& Uddin, M. A. (2016). Does Islamic bank financing lead to economic growth? An empirical analysis for Malaysia (Issue 69075).

Faiza, N. A. R. (2017). Pengaruh Alokasi Pembiayaan Sektor-Sektor Ekonomi oleh Perbankan Syariah terhadap Produk Domestik Regional Bruto (PDRB) Provinsi Jawa Timur. DigilibUIN Surabaya, 63-81.

Otoritas Jasa Keuangan. (n.d.). Statistik Perbankan Syariah. Otoritas Jasa Keuangan.

Setiawan, I. (2017). Peran Perbankan Syariah Terbadap Perekonomian Di Indonesia ( Pendekatan Model VAR / VECM ). 11(2), 172-178.

Sugiyono. (2015). Metode Penelitian Pendidikan (Pendekatan Kuantitatif, Kualitatif, dan R\&D) (Cetakan 21). Alfabeta, cv.

Suryana. (2010). Metodologi Penelitian. Universitas Pendidikan Indonesia.

Tripuspitorini, F. A., \& Setiawan, S. (2020). Pengaruh faktor makroekonomi terhadap pertumbuhan dana pihak ketiga pada bank umum syariah di Indonesia. Jurnal Riset Akuntansi dan Keuangan, 8(1), 121-132. 